\title{
The Carbon Sequestration Potential of Converting Sweet Chestnut Coppice Biomass into Biochar
}

\author{
Ida Bagus Mandhara Brasika, Julia Mason, Luis Brown Castellanos, Marika Samuelsson
}

\begin{abstract}
Biochar has been suggested as a means of abating climate change through long-term soil carbon storage. Amongst the various species found in coppiced woods, sweet chestnut could provide sufficient biomass feedstock. The model is comprised of three components: 1.) A biomass model considering the optimum rotation length for maximising annual biomass harvest, 2.) a cost model accounting for the harvesting and chipping of the biomass, exploring the optimum rotation length for minimum cost, and 3.) a model projecting the carbon storage under unmanaged and a new coppicing regime where coppice biomass is converted into biochar production. The findings show how long it would take for a new coppicing and biochar producing regime to become carbon negative. The model projects a coppicing regime which will take at least 82 years to become carbon negative.
\end{abstract}

Keyword - Biochar, Carbon Sequestration, Coppice, Sweet Chestnut.

\section{INTRODUCTION}

To withdraw the $\mathrm{CO}_{2}$ already in the atmosphere, the only readily deployable methods are CCS and the enhancement of biological sinks as the other alternatives simply inhibit or lessen further $\mathrm{CO}_{2}$ emissions. As acknowledgement over the obstacles of CCS (Carbon Capture Storage) has been mounting, such as its energy intensity, its cost and long-term storage issues, the alternative of developing methods to enhance biological sinks has been gaining more consideration (Darko, 2010). One such method is the production and deposition of biochar, most simply defined as charcoal produced primarily for use in environmental management.

The production of biochar and its application to soil is gaining recognition as a novel approach in creating a long-standing sink of atmospheric $\mathrm{CO}_{2}$ in terrestrial ecosystems. The application of biochar is not only capable of increasing the carbon storage of soils, but also provides benefits through enriched soil fertility and improved crop production (Darko, 2010). Biochar can be produced from almost any organic matter that is uncontaminated, such as crop residues, grasses, agricultural plant residues, stem timber and non-stem logging residues including tree-tops, branches and bark (Sohi, 2012). The use of different sources of biomass hold varying strengths and benefits. Furthermore, the choice of biomass type ought to hold the capacity to provide a steady supply in order to maintain a stable production of biochar.

In the British context, a potential source of biomass may be found in coppice woodlands, particularly those which have been abandoned because they are no longer economically viable (Evans, 1992). Coppicing is a forestry management practice whereby trees are cut periodically and allowed to regrow, ensuring a continuous regeneration of woodland and continuous supply.

The aim of this project is to determine the potential carbon sequestration benefit from bringing abandoned sweet chestnut (Castanea sativa) coppice woodland in the South East of England back into active coppice management and converting its biomass into biochar. Sweet chestnut has been chosen amongst the other species found in coppiced woods as they are the most predominant in England in terms of availability.

The specific modelling objectives of the project are as follows: a. Determine the optimum rotation cycle to deliver maximum biomass and minimum cost in order to propose a new coppicing regime for abandoned woodland

b. Project the net carbon sequestration throughout time to determine the point at which the production of biochar becomes carbon neutral

\section{THE METHOD OF THE STUDY}

The model developed for this project is divided into three components as shown in Figure 9. The first stage is the biomass model includes a growth function for sweet chestnut coppice, and aims to explore what the optimum rotation length would be to maximise yearly biomass production per hectare.

The second stage models the costs associated with harvesting and chipping the biomass to prepare it as feedstock for biochar production. The costs of production change with rotation length so this allows identification of an optimum which minimises costs for comparison with the optimum for biomass.

The last stage of the model projects how the carbon storage would change over time England's abandoned chestnut coppices were brought under a new coppicing regime with the biomass diverted to biochar production. For comparison it also projects how the carbon currently stored in those abandoned coppices would develop if no new coppicing regime were established and they were just left to continue growing.
Manuscript received September 7, 2017. This work was supported in part by the Center of Environmental Policy, Imperial College London.

Ida Bagus Mandhara Brasika, Julia Mason, Luis Brown Castellanos, Marika Samuelsson are with CEP, Imperial College London (Email: mandharabrasika@gmail.com). 


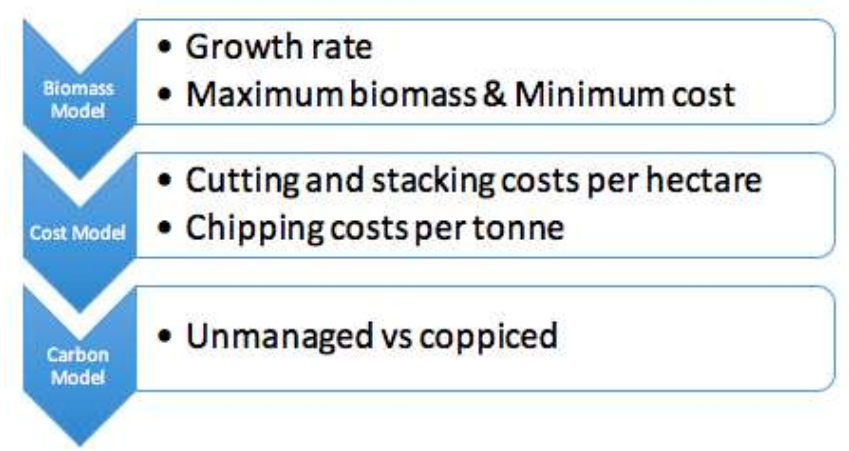

Fig. 1 The diagram of model methodology A more detailed model structure is explained in the flowchart (Figure 2) .

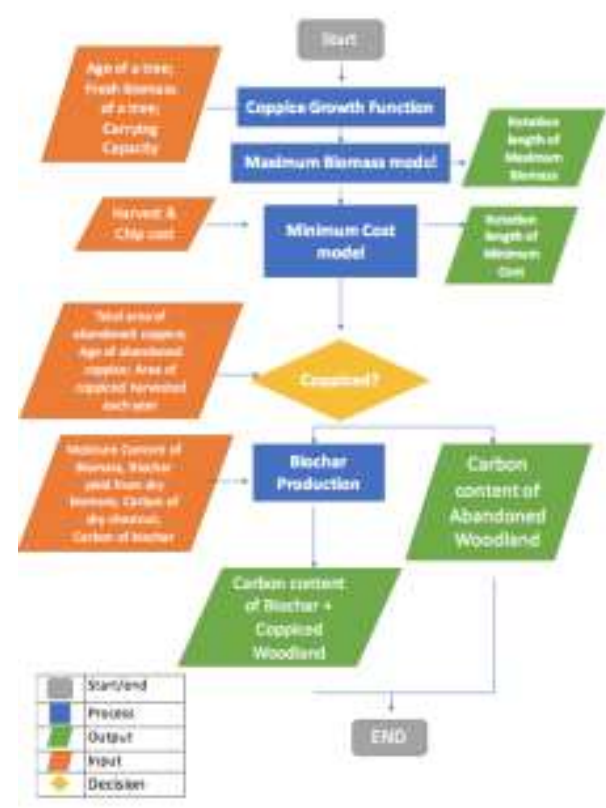

Fig. 2 The flowchart of the model structure

\section{A. Biomass model}

\section{B. Coppice biomass growth function:}

The coppice growth function presented here is based on biomass yield observations reported by Rollinson and Evans (1987). Their study measured a range of variables to develop a function that could be used as a field tool to predict the yield of any given area of UK sweet chestnut coppice. The data collected included age, mean diameter at breast height, number of shoots and stools per hectare. Despite a considerable range in stocking density (shoots and stools per hectare), they concluded that age alone was a satisfactory predictor of biomass.

Rollinson and Evans (ibid) sampled coppices up to 28 years since the last harvest, and used a quadratic function as their yield prediction model. However, for this paper it is necessary to model the biomass of abandoned coppice which may be older than 60 years. Assuming that the biomass of chestnut coppice will at some point be limited by density, a quadratic growth function was not deemed suitable. A logistic function was preferred, but given the level of uncertainty in carrying capacity it was necessary to use an asymmetric function that could accommodate different values whilst still giving a good fit to the data.

Adapting the flexible logistic function proposed by Richards (1959), the coppice biomass yield function used in this model is as follows:

$$
B=\frac{K}{(1+Q \cdot e-r \cdot a)^{\frac{1}{1}}}
$$

Where: $\mathrm{B}=$ above ground biomass (tonnes per hectare)

$\mathrm{K}$ = carrying capacity (tonnes per hectare)

$\mathrm{Q}=$ biomass at starting year (tonnes per hectare)

$\mathrm{r}=$ intrinsic growth rate $\mathrm{a}=$ age of coppice (years)

$\mathrm{v}=\mathrm{a}$ constant which determines the level of asymmetry with regards the point of inflexion

To allow investigation of the model's sensitivity to $\mathrm{K}$, the solver add-in and custom macros in Excel were used to automate iterative adjustments to the constants $\mathrm{Q}, \mathrm{r}$ and $\mathrm{v}$ to create functions that fitted the observations while varying the value of $\mathrm{K}$ (Figure 3 ).

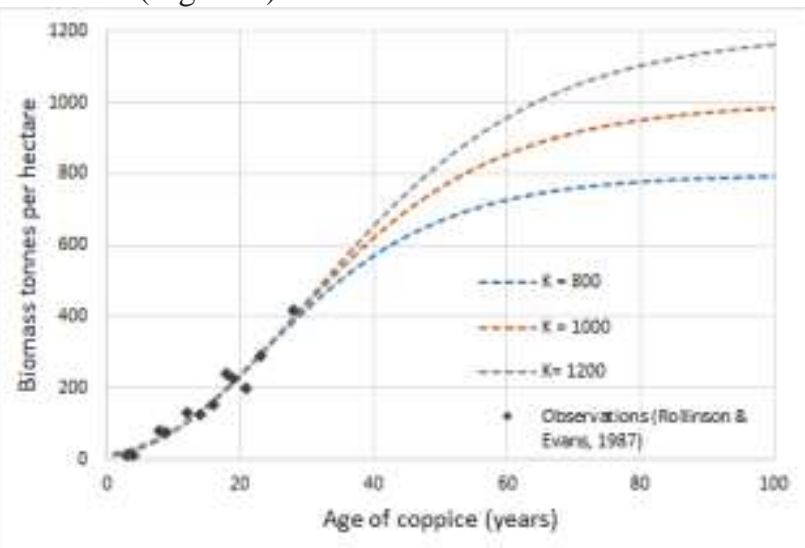

Fig. 3 Plot showing Richards' curve fit to observations from Rollinson and Evans (1987), using three different carrying capacities (K). $\mathrm{R}^{2}$ above 0.9 in each case.

Residuals analysis of the fit to observations shows fairly random distribution of residuals, except in the early years where biomass tends to be overestimated by the function (Figure 4).

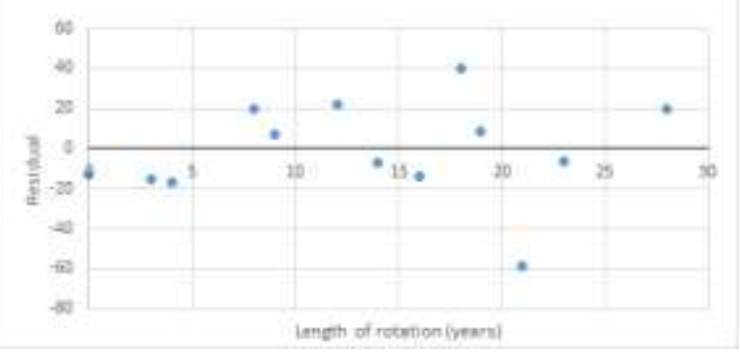

Fig. 4 Residual plot for coppice growth function where $\mathrm{K}=1000$.

i. Biomass harvestable for a given rotation length, per hectare of available coppice:

The growth function described above gives a biomass yield for a hectare of coppice harvested at a given age. However for a steady level of production year after year for a given rotation length, it is not possible to harvest all of the available coppice area every year. In a two year rotation only half of the available coppice area can be harvested, in a three year rotation only a third can be harvested, and so on. The area harvestable each year for a given rotation can be expressed as follows:

$$
H=\frac{A}{L}
$$


Where $\mathrm{H}=$ hectares harvestable each year, $\mathrm{A}=$ total hectares of available coppice, and $\mathrm{L}=$ the rotation length in years. Combining this with the growth function gives the equation for the biomass harvestable each year, $\mathrm{Bh}$, for a given rotation length and total area of available coppice.

$$
B h=H \cdot \frac{K}{(1+Q \cdot e-r \cdot L)^{\frac{1}{1}}}
$$

\section{Cost model}

ii. Cutting and stacking costs per hectare :

The cost of cutting the coppice and gathering the material on site is modelled as follows:

$$
C h=\frac{C f}{A h}
$$

Where $\mathrm{Cf}=$ daily cost of forest craftsperson, and $\mathrm{Ah}=$ area harvestable in a day by a forest craftsperson. Ah is itself a function of biomass harvested per hectare, since it is expected that the more material that needs cutting and handling, the slower the work rate. An exponential decrease in Ah with increasing biomass was developed based on discussion in an online forest worker's forum (Arbtalk, 2009), to give the following relationship:

$$
A h=0.1688 e^{-0.003 \cdot B}
$$

An inverse exponential decrease was chosen based on the assumption that the area harvestable per forest craftsperson would never be zero, and that efficiency of work would increase with biomass due to economies of scale.

\section{iii. Chipping costs per tonne}

Once the coppice is harvested and stacked, it must be chipped in preparation for transport and processing into biochar. The cost of chipping per tonne of biomass is given by:

$$
C t=\frac{C c}{W h \cdot K c}
$$

Where $\mathrm{Ct}=$ cost per tonne chipped, $\mathrm{Cc}=$ daily cost of chipper and operator, $\mathrm{Wh}=$ hours of operation in a day, and $\mathrm{Kc}$ $=$ hourly capacity of chipper in tonnes. The values actual values used for these variables were based on standard costs from the Forestry Commission (2011) and chipper specifications from a popular chipper manufacturer (Timberwolf, 2017).

iv. Cost per tonne of chip production for a given rotation.

The cost per tonne of chip produced is calculated from the cutting and stacking costs per hectare $(\mathrm{Ch})$, divided by the biomass produced by that hectare at the given rotation (B), plus the chipping costs per tonne $(\mathrm{Ct})$.

$$
C p=\frac{C h}{B}+C l
$$

\section{Carbon model}

The carbon model simulates carbon storage under three scenarios: no new coppicing of previously abandoned, new coppicing at the optimum for maximum biomass production, and new coppicing at the optimum for minimum cost per tonne of chip.

Some key assumptions in this model include:

- All the abandoned coppice in England is the same age (60 years).

- The carrying capacity of all coppice is the same (1000 tonnes per hectare). A list of the variables and parameters used is

\begin{tabular}{|c|c|c|}
\hline \multicolumn{3}{|c|}{ Notation Variable/ Parameter Explanation } \\
\hline$[\mathrm{x}]$ & $\begin{array}{l}\text { Years from start of new coppicing } \\
\text { regime }\end{array}$ & $\mathrm{x}=1 \ldots \ldots \mathrm{L}$ \\
\hline [Ta] & $\begin{array}{l}\text { Average age of abandoned coppice } \\
\text { chestnut woodland }\end{array}$ & \\
\hline [A] & $\begin{array}{l}\text { Total area of abandoned coppice } \\
\text { chestnut woodland }\end{array}$ & \\
\hline$[\mathrm{K}]$ & Carrying capacity & \\
\hline$[\mathrm{L}]$ & The length of rotation year & $\begin{array}{l}\text { Output of } \\
\text { biomass model }\end{array}$ \\
\hline$[\mathrm{H}]$ & The harvested area in a year & $=\mathrm{A} / \mathrm{L}$ \\
\hline [d] & $\begin{array}{l}\text { Conversion rate of fresh biomass to dry } \\
\text { biomass }\end{array}$ & \\
\hline [i] & Carbon content of dry chestnut biomass & \\
\hline [j] & Carbon content of biochar & \\
\hline$[\mathrm{k}]$ & $\begin{array}{l}\text { Conversion rate of biochar from dry } \\
\text { biomass }\end{array}$ & \\
\hline$[\mathrm{Bh}]$ & Harvested biomass & $\begin{array}{l}\text { Output of } \\
\text { biomass model }\end{array}$ \\
\hline
\end{tabular}
summarised in Table 1.

TABLE 1.

SUMMARY OF LIST OF VARIABLES AND PARAMETERS USED IN THE BIOMASS MODELS

v. Carbon storage in abandoned coppices with no new coppicing regime.

The first scenario projects how the carbon storage in the abandoned coppice develops over time if no new coppicing regime is established. This is relatively easily calculated using the biomass growth function, starting at the age of the abandoned coppice and applying the fresh to dry weight (d) and carbon content (i) conversion factors. The values used are 50\% (Rollinson and Evans, 1987), and 48.4\% (Montero et al., 2005) respectively. So the carbon content of the unmanaged woodland is represented by:

$$
\alpha=\left[A \cdot \frac{K}{\left(1+Q e^{-(T a+1}(u-1)^{\frac{1}{7}}\right)^{\frac{1}{7}}}\right] \cdot d \cdot i
$$

Alpha is the total amount of carbon content of abandoned chestnut coppice if no new coppicing regime is established.

\section{Carbon storage in coppice woodland and biochar sink under a newly established coppicing regime}

The carbon content of abandoned coppice brought under a new management regime is more complex as it requires 
calculation of carbon in standing biomass and accumulation in the biochar sink. The carbon stored in the abandoned coppice will decrease each year as an increasing portion is brought under the new coppice rotation cycle. To begin with the yearly biomass yield for biochar production will relate to the age of the remaining abandoned coppice and will increase with age until the end of the first rotation. At this point the biomass yield will relate to the age of the coppice at the end of the chosen rotation cycle. When the first first rotation, no carbon will be stored in what is class The first scenario projects how the carbon storage in the abandoned coppice develops over time if no new coppicing regime is established. This is relatively easily calculated using the biomass growth function, starting at the age of the abandoned coppice and applying the fresh to dry weight (d) and carbon content (i) conversion factors. The values used are 50\% (Rollinson and Evans, 1987), and 48.4\% (Montero et al., 2005) respectively. So the carbon content of the unmanaged woodland is represented by:

$$
\alpha=\left[A \cdot \frac{K}{\left(1+Q e^{-r\left(T a+x_{(K-1)^{2}}\right)^{\frac{1}{\gamma}}}\right.}\right] \cdot d \cdot i
$$

Alpha is the total amount of carbon content of abandoned chestnut coppice if no new coppicing regime is established. ified as abandoned coppice. As abandoned coppice is converted, the carbon stored in the newly managed coppice will increase every year as the area expands and the biomass grows. At the end of the first rotation the carbon stored in the newly coppiced area will reach a steady state, as will the biomass yield for biochar production.

Therefore the total carbon storage in each year is calculated as the carbon in the remaining abandoned forest, plus the carbon in the newly coppiced area, plus the cumulative carbon stored in the biochar. Equations for the components of these calculations are shown below.

Above ground biomass of remaining abandoned forest:

$$
\mathrm{O}=\left[\left(A-H_{x}\right) \cdot\left(\frac{K}{\left(1+Q e^{-r\left(T_{\alpha}+l_{x}\right)}\right)^{\frac{1}{v}}}\right)\right]
$$

$\mathrm{x}=1 \ldots \mathrm{L}$

$\mathrm{O}$ is the amount of biomass above ground in old (abandoned) chestnut woodland. This area will decrease with time because the harvested area $\left(\mathrm{H}_{\mathrm{X}}\right)$ is increasing every year until all of abandoned forest is replaced by the newly coppiced woodland.

Above ground biomass of newly coppiced area - N (using Simpson's rule):

$$
\mathrm{N}=\left[\left(\frac{t_{(x-1)}}{6}\right) \cdot\left(B_{1}+B_{x}+\frac{4 K}{\left(1+Q e^{-m}\right)^{\frac{1}{b}}}\right)\right]
$$

$\mathrm{N}$ is the amount of standing biomass in the newly managed chestnut woodland i.e. the area where the chestnut will regrow after coppicing. This store will increase and then become stable at the end of the first rotation year because the whole area will have been converted to newly coppiced area. The amount of biomass in the newly coppiced area is calculated from the biomass growth function using Simpson's integral rule . Carbon content of total standing coppice biomass:
The carbon content of the above ground biomass is calculated by summing the biomass in the remaining abandoned coppice area and the newly coppiced area, and applying conversion factors for dry biomass and carbon content.

$$
\beta=(O+N) . d . i
$$

Beta represents the total amount of carbon in the standing chestnut woodland under a new coppicing regime.

\section{Carbon content of biochar:}

It is assumed that the biochar produced from the chestnut biomass is ultimately applied to farmland and that it is indefinitely stable in the soil. Therefore the carbon stored in biochar is calculated cumulatively to include all biochar produced in since the beginning of production. The biochar carbon store in a given year is given by.

$$
\gamma=\left[\left(B h_{x} \cdot d \cdot k \cdot j\right)+\gamma_{(x-1)}\right]
$$

Where Gamma is the amount of carbon in biochar sink. The mass conversion of biochar from dry chestnut biomass is $24.4 \%$ (Ronsse 2013) and the carbon content of biochar is $91.8 \%$ (ibid).

Overall carbon stored in standing coppice and biochar sink:

The carbon store (delta) for a given year under the new coppicing regime is simply the sum of the carbon in the above ground (standing) biomass and the accumulation of biochar production.

$$
\delta=\beta+\gamma
$$

Delta is the crucial part of this model as the potential of biochar production is determined by the comparison of delta with alpha (carbon content of abandoned coppice in the "do nothing" scenario). The "break even" point for coppice biochar production in terms of carbon storage occurs delta more than alpha.

\section{THE RESULTS}

\section{A. Optimum Rotation Model}

The optimum rotation is modelled twice, first to find the rotation length at which the maximum biomass can be harvested (Figure 5) and second to find the rotation at which the harvest and chip preparation costs would be the lowest (Figure 6).

\section{B. Optimum rotation for maximum biomass}

The rotation length that produces the maximum biomass yield is 42 years. At this age of sweet chestnut coppice the harvest would be 15.5 tonnes/ha and would cost $£ 18.41 /$ tonne to harvest and cut into chip form. The peak at year one has been ignored in consideration of the optimum because the residual plot of the coppice growth function showed that biomass tended to be overestimated in very young coppices compared to observed values. 


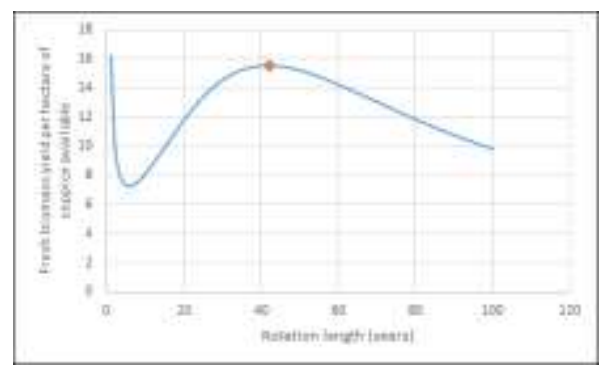

Fig. 5 Optimum rotation for maximum biomass yield. Fresh biomass harvest yield in tonnes per hectare at different coppice rotation lengths

\section{Optimum rotation for minimum cost of coppice wood chip produced}

The rotation length resulting in the biomass harvest yield with the minimum cost is 25 years. At this rotation the fresh biomass yield would equate to 13.42tonnes/ha and cost $£ 16.03 /$ tonne or $£ 215 /$ ha.

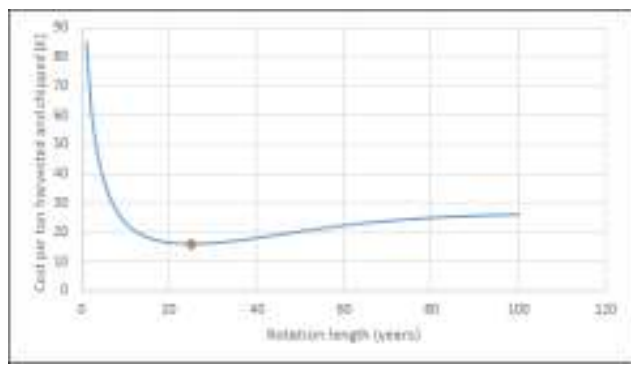

Fig. 6 Fresh biomass harvest yield per hectare at different coppice rotation lengths.

The results for the two optimal coppice rotations are summarised in Table II:

TABLE II.

OPTIMUM ROTATION RESULTS SUMMARY

\begin{tabular}{|l|l|l|}
\hline $\begin{array}{l}\text { Optimum rotation for } \\
\text { harvesting coppice }\end{array}$ & $\begin{array}{c}\text { Maximum } \\
\text { Biomass } \\
\text { harvested }\end{array}$ & $\begin{array}{l}\text { Minimum } \\
\text { harvesting } \\
\text { cost }\end{array}$ \\
\hline $\begin{array}{l}\text { Optimum rotation length } \\
\text { (years). }\end{array}$ & 42 & 25 \\
\hline $\begin{array}{l}\text { Fresh biomass yield at } \\
\text { optimum (tonnes). }\end{array}$ & 15.5 & 13.42 \\
\hline \begin{tabular}{l} 
Cost per tonne of chip (£) \\
\hline
\end{tabular} & 18.41 & 16.03 \\
\hline
\end{tabular}

\section{Optimum rotation - sensitivity results}

The sensitivity analysis shows that past 24 years the tonnes of fresh biomass harvested per hectare becomes less predictable. The original value of $\mathrm{K}$ gives a optimum rotation for maximum biomass harvest at 42 years, the lower and upper limits differ by 6 years either side of the original, 34 and 48 years respectively (Figure 7).

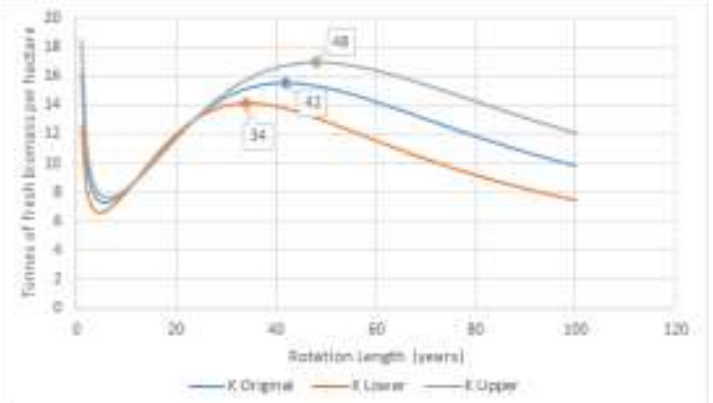

Fig. 7. The optimum fresh biomass sensitivity to the carrying capacity

\section{K. K sensitivity range has been set to $25 \%$.}

At the original value of $\mathrm{K}$ the optimum rotation based on minimum cost of coppiced wood chips is 25 years. The lower and upper limit of $\mathrm{K}$ to do not alter the rotation length.

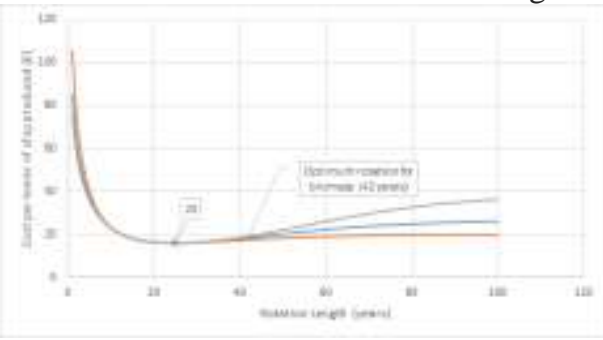

Fig. 8. The optimum cost sensitivity to the carrying capacity K.

\section{E. Projection of carbon storage in coppice and biochar sink}

Under an active coppice regime which centres on a rotation length for the minimum cost of coppicing, the carbon stored in the coppice and biochar sink will exceed the carbon stored under no coppicing by year 97 (Figure 9). The carbon stored under the scenario of active coppicing and biochar production will decrease due to carbon being released during coppice harvesting until year 25 .

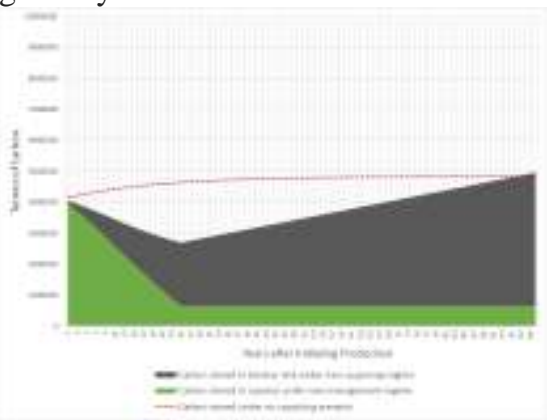

Fig. 9 Projection of Carbon Storage in Coppice and Biochar Sink under Rotation for Minimum Cost

Considering an active coppice regime characterised by a rotation length for maximum biomass, the carbon stored in the coppice and biochar sink will exceed the carbon stored under no coppicing by year 82 (Figure 10). The carbon stored under the scenario of active coppicing and biochar production will decrease until year 42 .

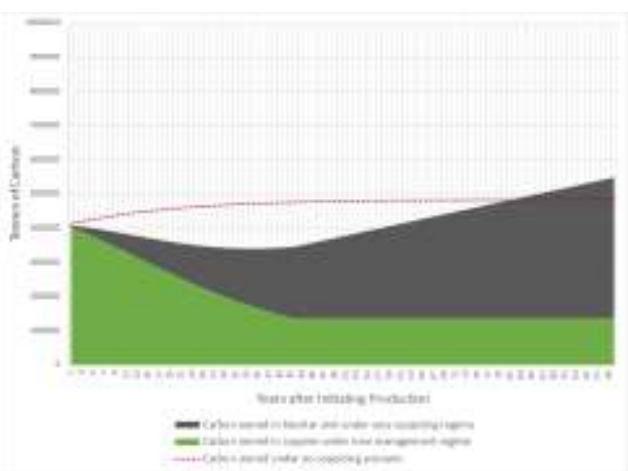

Fig. 10 Projection of carbon storage in coppice and biochar sink under rotation for maximum biomass

\section{F. Necessary period of time to double carbon storage relative to unmanaged coppice}

The carbon storage projection has been extended to show 
the year at which the carbon stored in the in coppiced woodland and biochar is double the carbon storage in unmanaged coppice woodland. The carbon storage carrying capacity of unmanaged woodland is 4,839 tonnes. In the scenario of choosing a minimum harvest cost rotation length ( 25 year rotation), Figure 11 illustrates that total carbon storage in the new coppice regime will reach 9,698 tonnes/year in year 257 .

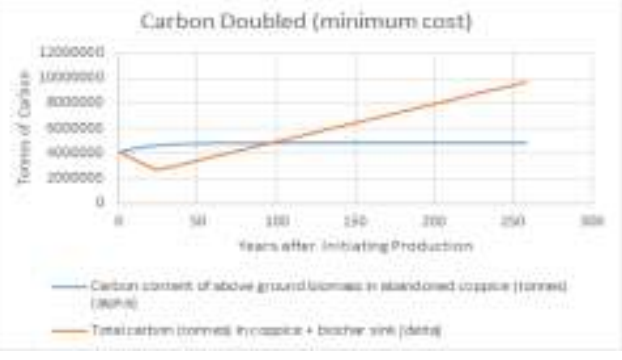

Fig. 11 Projection of carbon storage doubled under optimum rotation for minimum cost compared to the no coppice regime

The coppicing scenario for maximum biomass production, where the rotation year is 42 , shows slightly improved payback time (Figure 12). The carbon storage of coppiced woodland reaches 9,702 tonnes/year in 220 years. Even though the maximum biomass scenario is faster than minimum cost scenario, it will still take more than 200 years double carbon storage, through a biochar-coppicing management strategy.

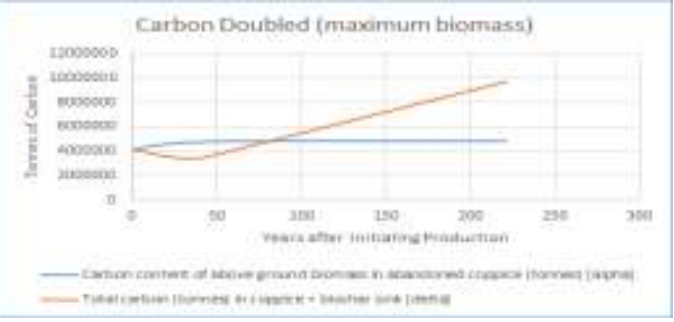

Fig. 12 Projection of carbon storage doubled under optimum rotation for maximum biomass compared to the no coppice regime

\section{SUMMARY AND DISCUSSION OF THE STUDY}

A conclusion section is usually required. Although a conclusion may review the main points of the paper, do not replicate the abstract as the conclusion. A conclusion might elaborate on the importance of the work or suggest applications and extensions.

\section{RECOMMENDATIONS FROM THE STUDY RESULTS}

In determining the potential carbon sequestration benefit from bringing abandoned sweet chestnut coppice woodland into active coppice management and converting its biomass into biochar, the model shows that it would require at least 82 years for the biochar production to become carbon negative. In the short-term, it would be more beneficial, in terms of carbon storage, for abandoned woodlands to be kept untouched. In the long term however, biochar production does create a carbon sink which, unlike standing forest, can accumulate indefinitely.

The scope the model does not account for the other potential benefits of biochar, such as it replacing fossil fuels through reduced fertiliser use and increased renewable energy. As such, a cost-benefit analysis and life-cycle analysis is recommended for further study in order to explore the potentials of biochar production more thoroughly. This would yield further knowledge and guidance to policy makers in determining whether coppice management and biochar production could be used as suitable approach for climate mitigation.y access to stores locations.

\section{ACKNOWLEDGMENT}

The preferred spelling of the word "acknowledgment" in American English is without an "e" after the "g." Use the singular heading even if you have many acknowledgments. Avoid expressions such as "One of us (S.B.A.) would like to thank ... ." Instead, write "F. A. Author thanks ... ." Sponsor and financial support acknowledgments are placed in the unnumbered footnote on the first page.

\section{REFERENCES}

[1] Arbtalk. (02/09/2009) Advice needed re Chestnut Coppice. Available from:

http://arbtalk.co.uk/forum/forestry-woodland-management/9418-advic e-needed-re-chestnut-coppice.html [Accessed 07/03/2017].

[2] Brown, A..H.F. \& Warr, S.J. (1992) The effects of changing management on the seed banks in ancient coppices. In: Buckley, G. P. (ed.).Ecology and management of coppice woodlands. London, Chapman \& Hall. pp. 147.

[3] Brown, R. (2009) Biochar production technology. Biochar for Environmental Management: Science and Technology. 127-146.

[4] Buckley, G. P. \& Howell, R. (2004) The ecological impact of sweet chestnut coppice silviculture on former ancient, broadleaved woodland sites in south-east England. , English Nature.

[5] Butterfly Conservation. (2017) Heath Fritillary. Available from: http://butterfly-conservation.org/679-987/heath-fritillary.html .

[6] Cowie, A., Woolf, D., Gaunt, J., Brandao, M., Anaya de la Rosa, Ruy \& Cowie, A. (2015) Biochar, carbon accounting and climate change. In: Johannes, L. \& Stephen, J. (eds.). Biochar for Environmental Management: Science, Technology and Implementation. second edition. , Routledge. pp. 763.

[7] Dierkes, C. (2011). Feature: Accounting for Carbon | Great Lakes Climate. [online] climategreatlakes.com. Available at: http://climategreatlakes.com/feature-accounting-for-carbon/ [Accessed 8 Mar. 2017].

[8] Elliott, D. C. (2007) Historical developments in hydroprocessing bio-oils. Energy \& Fuels. 21 (3), 1792-1815.

[9] Evans, J. (1992) Coppice forestry - an overview. In: Buckley, G. P. (ed.).Ecology and management of coppice woodlands. London, Chapman \& Hall. pp. 18.

[10] Foereid, B., Lehmann, J. \& Major, J. (2011) Modeling black carbon degradation and movement in soil. Plant and Soil. 345 (1-2), 223-236.

[11] Forestry Commission. (2011) Operations note 9: Standard Costs. Available

from: https://www.forestry.gov.uk/pdf/ewgs-on009-standard-costs.pdf/\$FILE lewgs-on009-standard-costs.pdf [Accessed 06/03/2017].

[12] Fuller, R. J. (1992) Effects of coppice management on woodland breeding birds. In: Buckley, G. P. (ed.).Ecology and management of coppice woodlands. London, Chapman \& Hall. pp. 169.

[13] Fuller, R. \& Moreton, B. (1987) Breeding bird populations of Kentish sweet chestnut (Castanea sativa) coppice in relation to age and structure of the coppice. Journal of Applied Ecology. 13-27.

[14] Fuller, R., Warren, M. S., Joint Nature Conservation Committee \& Britain, G. (1993) Coppiced woodlands: their management for wildlife. , Joint Nature Conservation Committee Peterborough, UK.

[15] GEA. (2012) Global Energy Assessment - toward a sustainable future. Cambridge, UK, and Laxenburg, Austria: Cambridge University Press and the International Institute for Applied Systems Analysis.

[16] Greatorex-Davies, J. N. \& Marrs, R. H. (1992) The quality of coppice woods as habitats for invertebrates. In: Buckley, G. P. (ed.).Ecology and management of coppice woodlands. London, Chapman \& Hall. pp. 271.

[17] Gurnell, J., Hicks, M. \& Whitbread, S. (1992) The effects of coppice management on small mammal populations. In: Buckley, G. P. (ed.).Ecology and management of coppice woodlands. London, Chapman \& Hall. pp. 213.

[18] IPPC, Metz, B., Davidson, O., De Coninck, H., Loos, M. \& Meyer, L. (2005) IPCC Special Report on Carbon Dioxide Capture and Storage.

[19] Lee, Y., Eum, P., Ryu, C., Park, Y., Jung, J. \& Hyun, S. (2013) Characteristics of biochar produced from slow pyrolysis of Geodae-Uksae 1. Bioresource Technology. 130 345-350.

[20] Lehmann, J. \& Joseph, S. (2009) Biochar for Environmental Management: An Introduction. In: Lehmann, J. \& Joseph, S. (eds.). 
Biochar for Environmental Management: Science and Technology. Revised edition., Routledge. pp. 1.

[21] Lehmann, J., Skjemstad, J., Sohi, S., Carter, J., Barson, M., Falloon, P., Coleman, K., Woodbury, P. \& Krull, E. (2008) Australian climate-carbon cycle feedback reduced by soil black carbon. Nature Geoscience. 1 (12), 832-835.

[22] Lehmann, J., Gaunt, J. \& Rondon, M. (2006) Bio-char Sequestration in Terrestrial Ecosystems â $€^{\prime \prime}$ A Review. Mitigation and Adaptation Strategies for Global Change. 11 (2), 395-419.

[23] Liang, B., Lehmann, J., Solomon, D., Sohi, S., Thies, J. E., Skjemstad, J. O., Luizao, F. J., Engelhard, M. H., Neves, E. G. \& Wirick, S. (2008) Stability of biomass-derived black carbon in soils. Geochimica Et Cosmochimica Acta. 72 (24), 6069-6078.

[24] Locke, G. (1987) Census of woodlands and trees 1979-82.

[25] Matovic, D. (2011) Biochar as a viable carbon sequestration option: Global and Canadian perspective. Energy. 36 (4), 2011-2016.

[26] McLaren, D. (2012) A comparative global assessment of potential negative emissions technologies. Process Safety and Environmental Protection. 90 (6), 489-500.

[27] Montero, G., Ruiz-Peinado, R. \& Muñoz, M. (2005) Producción de biomasa y fijación de $\mathrm{CO} 2$ por los bosques españoles. Instituto Nacional de Investigación y Tecnología Agraria y Alimentaria Madrid, España.

[28] Moss, R. H., Edmonds, J. A., Hibbard, K. A., Manning, M. R., Rose, S. K., Van Vuuren, D. P., Carter, T. R., Emori, S., Kainuma, M. \& Kram, T. (2010) The next generation of scenarios for climate change research and assessment. Nature. 463 (7282), 747-756.

[29] NCP, (2016). Carbon Storage and Sequestration: Climate Regulation InVEST +VERSION+ documentation. [online] Data.naturalcapitalproject.org. Available at: http://data.naturalcapitalproject.org/nightly-build/invest-users-guide/ht $\mathrm{ml} /$ carbonstorage.html\# [Accessed 7 Mar. 2017].

[30] Peterken, G. F. (1992) Coppices in the lowland landscape. In: Buckley, G. P. (ed.).Ecology and management of coppice woodlandsCoppi. London, Chapman \& Hall. pp. 1.

[31] Peterken, G. F. (. (1981) Woodland conservation and management. London, Chapman and Hall.

[32] Raupach, M. R., Marland, G., Ciais, P., Le Quéré, C., Canadell, J. G., Klepper, G. \& Field, C. B. (2007) Global and regional drivers of accelerating $\mathrm{CO} 2$ emissions. Proceedings of the National Academy of Sciences. 104 (24), 10288-10293.

[33] Richards, F. (1959) A flexible growth function for empirical use. Journal of Experimental Botany. 10 (2), 290-301

[34] Rollinson, T. \& Evans, J. (1987) The yield of sweet chestnut coppice. .

[35] Ronsse, F., Van Hecke, S., Dickinson, D. \& Prins, W. (2013) Production and characterization of slow pyrolysis biochar: influence of feedstock type and pyrolysis conditions. Gcb Bioenergy. 5 (2), 104-115.
[36] Shackley, S., Hammond, J., Gaunt, J. \& Ibarrola, R. (2011) The feasibility and costs of biochar deployment in the UK. Carbon Management. 2 (3), 335-356.

[37] Shackley, S., Ruysschaert, G., Zwart, K. \& Glaser, B. (2016) Biochar in European soils and agriculture: science and practice. , Routledge.

[38] Sohi, S. P. (2012) Agriculture. Carbon storage with benefits. Science (New York, N.Y.). 338 (6110), 1034-1035.

[39] Timberwolf. (2017) TW 230DHB, 6" Road Towed Wood Chipper. Available from: http://www.timberwolf-uk.com/products-woodchippers-and-shredders/ road-towable-hydraulic-woodchippers/tw-230dhb-chipper/\#specificati on [Accessed 06/03/2017].

[40] Verheijen, F., Jeffery, S., Bastos, A., Van der Velde, M. \& Diafas, I. (2010) Biochar application to soils. A Critical Scientific Review of Effects on Soil Properties, Processes, and Functions.EUR. 24099162.

[41] Warren, M. S. \& Thomas, J. A. (1992) Butterfly responses to coppicing. In: Buckley, G. P. (ed.).Ecology and management of coppice woodlands. London, Chapman \& Hall. pp. 247.

[42] Whitman, T. \& Lehmann, J. (2009) Biochar-One way forward for soil carbon in offset mechanisms in Africa? Environmental Science \& Policy. 12 (7), 1024-1027.

[43] Wikimedia Commons. (2010) Bluebells in Sweet Chestnut coppice at Flexham Park, Bedham near Petworth, West Sussex, England. .

[44] Winsley, P. (2007) Biochar and bioenergy production for climate change mitigation. New Zealand Science Review. 64 (1), 5-10.

[45] Woolf, D., Amonette, J. E., Street-Perrott, F., Lehmann, J. \& Joseph, S. (2010) Sustainable biochar to mitigate global climate change. Nature Communications. 156

Ida Bagus Mandhara Brasika is a master student at MSc. Environmental Technology, Imperial College. He was born at Denpasar, 23 June 1992. He gained his bachelor at Institut Technology Bandung as bachelor of meteorologywith focus study climate change. The main research is associated with the climate variability such as El Nino into environment.

$\mathrm{He}$ started his career as research assistant in Laboratorium of Environment Meteorology. Then, he continue to work for the Indonesian government at Environment Agency as Climate Change Analyst.

The best student of meteorology ITB has been awarded to him as his impression performance in 2013. Then, he gained award from Indonesian Endowment Fund to study environment resource management, mainly about forest fire study. 